\title{
Using an Algal Photo-Bioreactor as a Polishing Step for Secondary Treated Wastewater
}

\author{
Abdelsalam Elawwad ${ }^{1 *}$, Ahmed Karam², Khaled Zaher ${ }^{1}$ \\ ${ }^{1}$ Sanitary and Environmental Engineering Dept., Cairo University, 12613 Giza, Egypt \\ ${ }^{2}$ Civil Engineering Dept., Canadian International College, El-Sheikh Zayed City, Egypt
}

Received: 21 November 2016

Accepted: 11 January 2017

\begin{abstract}
In this study, the feasibility of utilizing an algal photo-bioreactor as a polishing step for secondary treated wastewater was tested. Algal photo-bioreactors utilize the interaction of bacteria and microalgae, which offers an eco-friendly and lower energy consumption technology for nutrient removal and biomass production. The pilot plant in this study consists of an algal photo-bioreactor with an effective volume of $0.188 \mathrm{~m}^{3}$ and a lamella settler, constructed and operated at Zenin Wastewater Treatment Plant, Giza, Egypt. The pilot plant was operated for about 112 days under continuous flow conditions at ambient temperature. The effect of hydraulic retention time (HRT) on the rate of removal of organics and nutrients was investigated at a fixed solid retention time of 15 days. The photo-bioreactor was continuously illuminated with light obtained during the day from sunlight and at night from incandescent lamps. HRT of 16.1 hours had the best overall organic and nutrient removal efficiency. However, from an economic standpoint the optimum applied load was $50 \mathrm{~g} \mathrm{~N} / \mathrm{d} / \mathrm{m}^{3}$ and $22 \mathrm{~g} \mathrm{P} / \mathrm{d} / \mathrm{m}^{3}$ for ammonia and phosphorus, respectively. These applied loads correspond to HRTs in the range of five to six hours and expected removal efficiencies above $85 \%$ and $70 \%$, respectively, for ammonia and phosphorus.
\end{abstract}

Keywords: tertiary treatment, algal photo-bioreactor, wastewater treatment

\section{Introduction}

Biological treatment of wastewater is the most common, efficient, and economical way to treat municipal wastewater. In many developing countries, there are few restrictions for nutrient removal in wastewater treatment; therefore, wastewater treatment plants (WWTPs) often produce secondary treated wastewater that contains elevated nutrient concentrations. Disposal of wastewater containing nutrients to waterways can cause eutrophication and affect public health [1]. In the future, more restrictions

*e-mail: elawwad@cu.edu.eg on nutrient removal are expected, and upgrading existing WWTPs by adding a tertiary treatment step will be required.

Recent developments in the field of biological wastewater treatment have led to renewed interest in non-conventional and environmentally friendly treatment technologies such as algae-based systems as an alternative method of removal of nutrients and toxic heavy materials. Algae-based systems have many advantages, including low energy requirements and high microalgae reproduction rates [2-4]. The produced microalgae can be used in different applications, such as for biogas production when co-digested with additional waste in conventional anaerobic digesters [5]. Alternatively, microalgae biomass 
can be used after treatment to produce biofertilizers for agricultural use. Moreover, new concepts are emerging for other algal biomass uses such as animal feed or chemicals, bioplastics, and biofuels [6].

It is widely agreed that microalgae can grow satisfactorily in wastewaters, which are rich in nitrogen and phosphorus. Algae-based wastewater treatment has been verified in the literature by numerous studies in recent decades $[3,4,7,8]$. In the past, microalgae were cultivated in oxidation ponds or high-rate algal raceway ponds [4]. However, open ponds require a large amount of space, and effluent water quality from such ponds is easily affected by loss of algal biomass because of the poor settleability of microalgae [2]. Therefore, research on algae-based wastewater treatment has recently focus on algal photobioreactors, which are effective, require a small footprint, have high algal biomass production, and can be controlled efficiently [9-11]. The coexistence of bacteria and microalgae in algal-bacterial systems improves organic matter and nutrient removal where microalgae deliver the oxygen required for heterotrophic and autotrophic bacteria while consuming the $\mathrm{CO}_{2}$ released by the bacteria $[6,12]$. It was previously reported that nitrifying organisms is a main contributor in ammonia removal by nitrification in a lab-scale photobioreactor [10]. However, excessive growth of microalgae may inhibit the growth of nitrifying bacteria [13].

Many factors affect microalgae growth and ability to remove nutrients. Some elements, such as calcium, iron, silica, magnesium, manganese, potassium, copper, sulfur, cobalt, and zinc, also influence algae development in wastewater [14], along with $\mathrm{pH}$, temperature, light, mixing, and dissolved oxygen, which influence development rates and chemical composition of microalgae in wastewater treatment systems. Changes in $\mathrm{pH}$ impact the bacterial action in algal-bacterial cultures. Photosynthesis of microalgae results in increases in $\mathrm{pH}$, which might hinder growth of bacteria [13]. However, the presence of nitrifying organisms helps to balance the system by removing ammonia and therefore decreasing $\mathrm{pH}$. Temperature is also a critical parameter in microalgae and heterotrophic bacteria development rates. The ideal development of microalgae happens in the range $16-27^{\circ} \mathrm{C}$. Temperatures less than $16^{\circ} \mathrm{C}$ downregulate the development of microalgae, while temperatures higher than $35^{\circ} \mathrm{C}$ are deadly for some species [15]. Biomass concentration on algal photo-bioreactor is significantly affected by hydraulic retention time (HRT) [16]. Recommendations suggest operating ordinary algal-bacterial systems with long HRTs and low loads. The algal-bacterial culture is not ready to completely remove ammonia from wastewater at high loads and short HRTs [17]. Biomass recycling (i.e., algal photo-bioreactor) reduces biomass washout, enables the system to be operated at shorter HRTs, and increases biomass [11].

Different studies have tested photo-bioreactors utilizing synthetic wastewater containing high and medium concentrations of nutrients or utilizing primary treated wastewater [9-11]. To our knowledge, limited studies have been undertaken on the feasibility of an algal photo-bioreactor as a polishing treatment step for secondary treated wastewater [18]. Therefore, the objective of this study was primarily to investigate the performance of a pilot-scale algal photo-bioreactor in treating real secondary treated wastewater produced from an existing WWTP under continuous flow conditions. Data gained from the pilot experiment will be helpful in designing and applying the system on a larger scale. Moreover, the effect of important operational parameters such as HRT and nutrient loading rates on organic and nutrient removal performance was evaluated. Finally, the dominant microalgae species at the beginning and end of the pilot experiment were identified.

\section{Materials and Methods}

A pilot plant was constructed and operated in Zenin WWTP, Giza, Egypt. The pilot plant consists of a feeding tank $\left(0.5 \mathrm{~m}^{3}\right)$, a photo-bioreactor $\left(0.188 \mathrm{~m}^{3}\right)$, a lamella settler $\left(0.1 \mathrm{~m}^{3}\right)$, and two pumps for sludge recycling. A schematic diagram of the treatment train is shown in Fig. 1. The photo-bioreactor was made of transparent acrylic, with internal dimensions of $50 \times 75 \mathrm{~cm}$ and a height of $50 \mathrm{~cm}$. It was equipped with two overhead stirrers working interchangeably $(120 \mathrm{rpm})$ with no aeration. The photo-bioreactor is fed through the feed tank with the secondary treated wastewater from the Zenin WWTP. This WWTP is based on an activated process with expected average effluent characteristics of chemical oxygen demand (COD) of 60-70 mg/L, $\mathrm{NH}_{4}-\mathrm{N}$ of $10-12 \mathrm{mg} / \mathrm{L}$, and $\mathrm{P}$ of $3-5 \mathrm{mg} / \mathrm{L}$. The effluent from the photo-bioreactor is then flowed to a lamella settler to settle the algal-bacterial biomass. The settled biomass is then recycled back to the inlet of the photo-bioreactor as shown in Fig. 1. The recycle flow rate (return sludge) was set at $30 \mathrm{~mL} / \mathrm{min}$ throughout the experimental period.

Among the most vital parameters determining the performance of photo-bioreactors is light intensity. Previous studies have reported different criteria for required light intensity for microalgae growth in photobioreactors. Microalgae growth is relative to the proficiency of light use. The microalgae light immersion point is regularly within $200-400 \mu \mathrm{mol} \mathrm{m}^{-2} \mathrm{~s}^{-1}$ [19]. The light period significantly affects the photosynthetic process and is an essential parameter for consideration in the design of photo-bioreactors. In this study, to sustain continuous illumination and at the same time reduce energy, light was obtained during the day from sunlight and at night from incandescent lamps (Fig. 1). The lamps were connected to a photocell so that they would switch on automatically at night. The photosynthetic photon flux density (PPFD) as an expression for light intensity was measured using a quantum light meter (FieldScout, STEP Systems GmbH, Germany). During the day, PPFD was measured at different times and days throught the experimental period and ranged between 800 and 1,700 $\mu \mathrm{mol} \mathrm{m} \mathrm{m}^{-2} \mathrm{~s}^{-1}$ at the top and sides of the photo-bioreactor. 


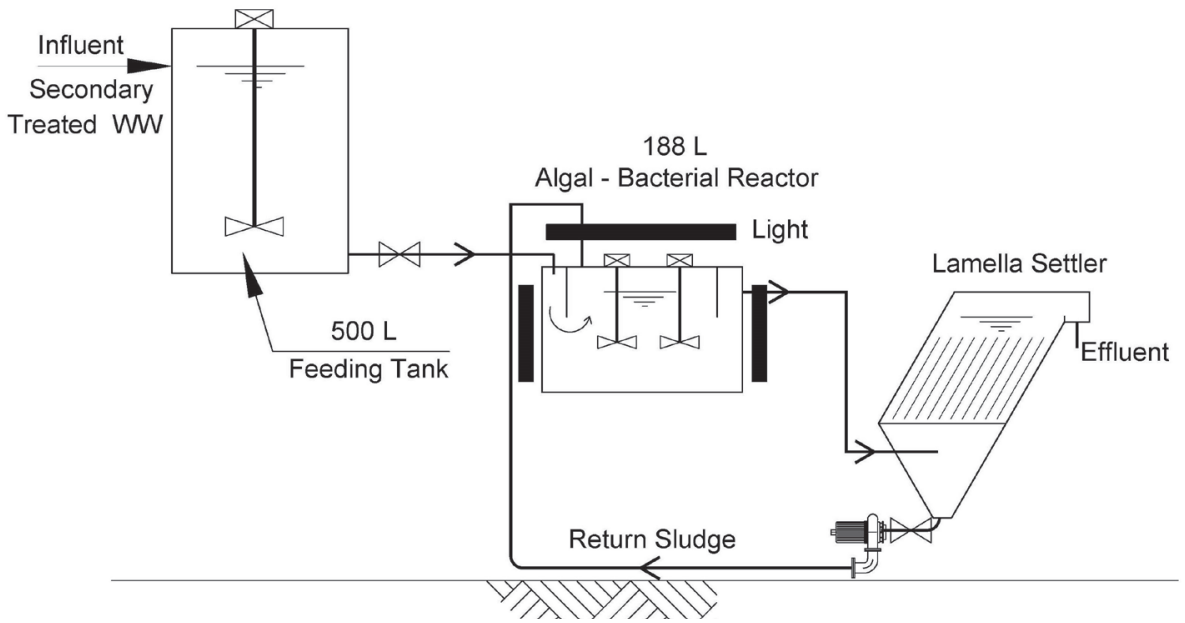

Fig. 1. Schematic diagram of the pilot plant

The intensity of the installed lamps at night was set to around $250 \mu \mathrm{mol} \mathrm{m} \mathrm{m}^{-2} \mathrm{~s}^{-1}$ at the top and sides of the photobioreactor.

For start-up, the photo-bioreactor was first filled with secondary treated wastewater. The photo-bioreactor was seeded with algal biomass from another experiment based on a high-rate algal pond. The seeded biomass was analyzed and found to contain mixtures of the following species: Scenedesmus, Spirulina, Ankistrodesmus, Closterium, and Anabaena. In addition, 15 liters of activated sludge (6.2 g TSS/L) from Zenin WWTP was added to the bioreactor. The mixture of secondary treated wastewater, algal biomass, and activated sludge was stirred in the reactor for 10 days before beginning continuous operation. Then, for continuous operation, the system was operated on an HRT of 24 hours and a solids retention time (SRT) of 15 days. In order to determine the role of HRT in optimal nutrient removal, the system was tested at different HRTs after reaching steady state, when the system was operated at an average HRT of $23.8 \mathrm{~h}$ for 16 days. Then the HRT was decreased and the system was operated at HRTs of 16.1, $12.1,8.5$, and $3.9 \mathrm{~h}$ for $18,15,20$, and 22 days, respectively. The total experimental period under continuous operation was 112 days at ambient temperature, excluding the initial 10-day batch period.

The system was operated at a fixed SRT of 15 days throughout the experimental period, as recommended by van der Steen et al. (2015) and Karya et al. (2013) [9, 10]. The excess sludge was removed daily from the bioreactor as a mixed liquor. Samples were collected 2 to 3 times per week from the inlet and outlet of the pilot plant. The collected samples were preserved at $4^{\circ} \mathrm{C}$ until analysis on the same day. The measured parameters included $\mathrm{pH}$, COD, biological oxygen demand (BOD), total suspended solids (TSS), volatile suspended solids (VSS), total Kjeldahl nitrogen $(\mathrm{TKN})$, ammonia-nitrogen $\left(\mathrm{NH}_{4}-\mathrm{N}\right)$, nitrite-nitrogen $\left(\mathrm{NO}_{2}-\mathrm{N}\right)$, nitrate-nitrogen $\left(\mathrm{NO}_{3}-\mathrm{N}\right)$, and total phosphorus (TP). All the analyses were performed according to the standard method [20]. The algal species in the seeded sludge and at the end of the experimental period were identified using a ZEISS AXIO Imager A2 microscope.

\section{Results and Discussion}

During the start-up phase, it took about 21 days to reach steady state after continuous operation. The organic and ammonia uptake increased gradually during this period until reaching about $45 \%$ and $80 \%$ for COD and ammonia removal, respectively. For ease of comparison, the different tested phases were numbered from 1 to 5 , corresponding to HRTs of $23.8,16.1,12.1,8.5$, and $3.9 \mathrm{~h}$, respectively. Table 1 summarizes the results of mixed liquor suspended solids (MLSS), influent and effluent COD, and influent and effluent TSS for the different phases. For phases 1 to 4, COD in the influent ranged between 58 and $74 \mathrm{mg} / \mathrm{L}$ and the effluent TSS was in the range of 18.5 to $32.9 \mathrm{mg} / \mathrm{L}$, indicating removal efficiency above $50 \%$ for most of the experimental period. In phase 5, during which HRT was $3.9 \mathrm{~h}$, the COD removal efficiency significantly decreased to $44 \%$ because of the wash-out of the algal biomass, confirmed by the decrease in MLSS concentration, as shown in Table 1. The same conclusion can be drawn for TSS removal. For phases 1 to 4 , TSS influent values ranged between 25.6 and $30.3 \mathrm{mg} / \mathrm{L}$, and the effluent TSS was around $10 \mathrm{mg} / \mathrm{L}$, indicating removal efficiency above $65 \%$ over most of the experimental period. In phase 5, during which HRT was $3.9 \mathrm{~h}$, the TSS removal efficiency decreased to $61.2 \%$. The removal of suspended solids depends on the ability of the lamella settler to settle the microalgae biomass. In this study, the settling time in the lamella settler was a minimum of two hours in phase 5, which is thought to be adequate in wastewater applications. Better harvesting for the fugitive algal biomass can be obtained by using membrane technology for separation of algal biomass [18]. However, the cost saving and membrane fouling could be detrimental for this technology. 
Table 1. MLSS, influent, and effluent COD and TSS and their removal at different HRTs.

\begin{tabular}{|c|c|c|c|c|c|c|c|c|}
\hline Phase & HRT & $\begin{array}{c}\text { MLSS } \\
\mathrm{g} / 1\end{array}$ & $\mathrm{COD}_{\text {inf }}$ & $\mathrm{COD}_{\text {eff }}$ & $\begin{array}{c}\text { Avg. COD } \\
\text { removal } \%\end{array}$ & TSS $_{\text {inf }}$ & TSS $_{\text {eff }}$ & $\begin{array}{c}\text { Avg. TSS } \\
\text { removal } \%\end{array}$ \\
\hline 1 & 23.8 & 1.32 & $60-74.4$ & $25.7-32.9$ & 57.9 & $27-30.3$ & $9-11.1$ & 65.3 \\
\hline 2 & 16.1 & 1.14 & $60-61.5$ & $18.5-21.6$ & 67.3 & $28-30.1$ & $9.2-11$ & 65.9 \\
\hline 3 & 12.1 & 118 & $60-90$ & $21.2-25.2$ & 54.9 & $28.2-32.6$ & $10-11$ & 66.9 \\
\hline 4 & 8.5 & 1.1 & $58.2-66$ & $19.9-25.7$ & 51.4 & $25.6-30.3$ & $9.2-11$ & 64.6 \\
\hline 5 & 3.9 & 0.56 & $60-66$ & $26.0-42.4$ & 44.6 & $21-30.1$ & $8.8-12$ & 61.2 \\
\hline
\end{tabular}

MLSS concentrations were gradually increased during the start-up period until reaching values around 1,200 $\mathrm{mg} / \mathrm{L}$ by the end of the start-up period. Operation of the system at SRT of 15 days was successful in sustaining the MLSS concentrations at 1,100 to $1,300 \mathrm{mg} / \mathrm{L}$ while reducing HRTs down to $8.5 \mathrm{~h}$, as shown in Table 1. In experiments with HRT of $4 \mathrm{~h}$, in which the influent flow increased to $1.16 \mathrm{~m}^{3} / \mathrm{d}$ on average, MLSS decreased by almost half to $558 \mathrm{mg} / \mathrm{L}$. This decrease could be a result of wash-out of the algal-bacterial flocs at this low HRT. MLSS concentrations in this study were comparable to the values reported in previous laboratory studies with conditions similar to those of this study [9-10]. Van der Steen et al. (2015) [9] operated a laboratory-scale SBR photo-bioreactor at biomass VSS concentration of $736 \mathrm{mg} / \mathrm{L}$ at SRT of 15 days and HRT of $24 \mathrm{~h}$. However, this is lower than values reported by Karya et al. (2013) [10] in an SBR photo-bioreactor operated at SRT of 15 days and MLSS concentrations up to $2.41 \mathrm{~g} / \mathrm{L}$. MLSS concentrations in the range of 0.5 to $2.0 \mathrm{~g} / \mathrm{L}$ are expected and depend on the photo-bioreactor type and the culture conditions [6].

Fig. 2 shows the ammonia and phosphorus concentrations in the effluent and effluent of photo- bioreactor. Table 2 summarizes the influent and effluent ammonia and phosphorus concentrations found at the different HRTs. Nutrient removal in the photo-bioreactor is much better than organic removal throughout the experimental period. For phases 2 to 4 , the removal of ammonia and phosphorus was acceptable, with removal efficiencies above $85 \%$ and $60 \%$, respectively. In phase 5 , during which HRT was $3.9 \mathrm{~h}$, ammonia removal efficiency decreased significantly to $63.1 \%$. This is because of algal biomass wash-out, as discussed above. The best performance was obtained at HRT of $16.1 \mathrm{~h}$, with average removal efficiencies of $90.2 \%$ and $85.6 \%$ for ammonia and phosphorus, respectively. While the removal by percentage of phosphorus looks smaller than that of ammonia (Table 2), in fact the system achieved good removal of phosphorus as the effluent phosphorus concentrations did not exceed $2 \mathrm{mg} / \mathrm{L}$ for phases 1 to 4 . Phosphorus in the influent water was low and in the range of 3 to $6 \mathrm{mg} / \mathrm{L}$. Comparing the results of all parameters, it can be concluded that HRT of $16.1 \mathrm{~h}$ shows the best overall efficiency with regard to organic and nutrient removal, as shown in Tables 1 and 2. The removal efficiencies obtained in the algal photo-bioreactor in this study are comparable to the literature.

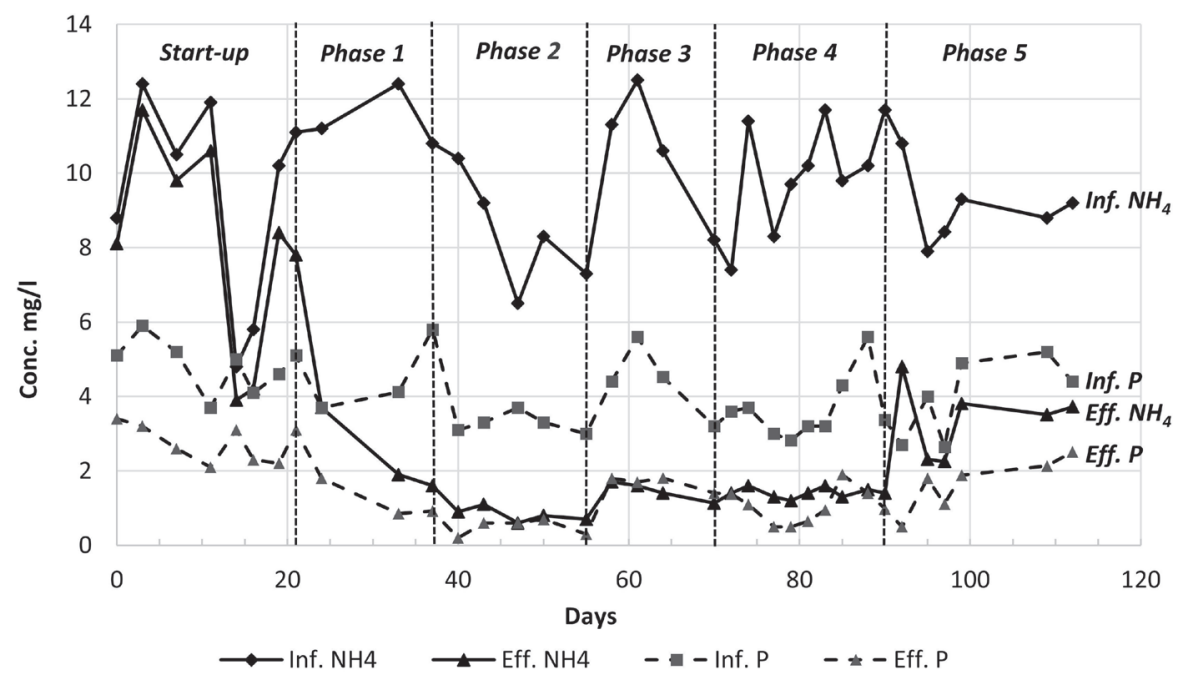

Fig. 2. Ammonia and phosphorus concentrations in the influent and effluent of photo-bioreactor (Units are in mg N/1 and mg P/l for ammonia and phosphorus, respectively). 
Table 2. Influent and effluent ammonia and phosphorus and their removal at different HRTs.

\begin{tabular}{|c|c|c|c|c|c|c|c|}
\hline Phase & HRT & Inf. $\mathrm{NH}_{4}$ & Eff. $\mathrm{NH}_{4}$ & $\begin{array}{c}\text { Avg. } \mathrm{NH}_{4} \\
\text { removal } \%\end{array}$ & Inf. P & Eff. P & $\begin{array}{c}\text { Avg. P removal } \\
\%\end{array}$ \\
\hline 1 & 23.8 & $10.8-12.4$ & $1.6-3.7$ & 78.9 & $3.7-5.8$ & $0.9-1.8$ & 71.6 \\
\hline 2 & 16.1 & $6.5-10.4$ & $0.6-1.1$ & 90.2 & $3.0-3.7$ & $0.2-0.7$ & 85.6 \\
\hline 3 & 12.1 & $8.2-12.5$ & $1.1-1.7$ & 86.3 & $3.2-5.6$ & $1.4-1.8$ & 61.2 \\
\hline 4 & 8.5 & $7.4-11.7$ & $1.2-1.6$ & 85.7 & $2.8-5.6$ & $0.5-1.9$ & 72.1 \\
\hline 5 & 3.9 & $7.9-10.8$ & $2.3-4.8$ & 63.1 & $2.6-5.2$ & $0.5-2.5$ & 59.7 \\
\hline
\end{tabular}

At the same SRT of 15 days and HRT of 24 hours, van der Steen et al. (2015) [9] obtained an ammonia removal efficiency up to $85 \%$ in a lab-scale photo-bioreactor using synthetic wastewater with ammonia concentration of 66 mg N/l. However, higher ammonia removal efficiency was obtained in modified SBR photo-bioreactor systems [10]. In general, it expected to have better performance SBR treatment systems than in continuous flow systems. Karya et al. (2013) [10] examined two SRT values of 15

a)

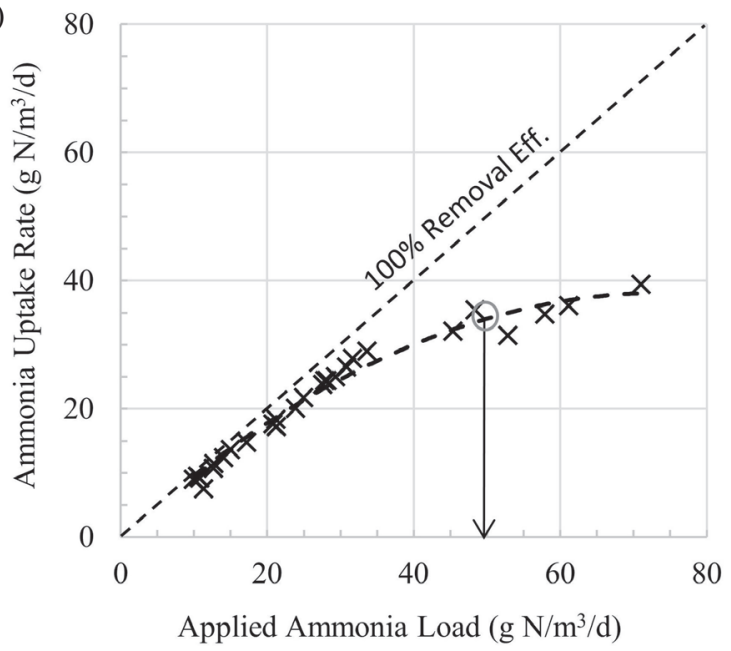

b)

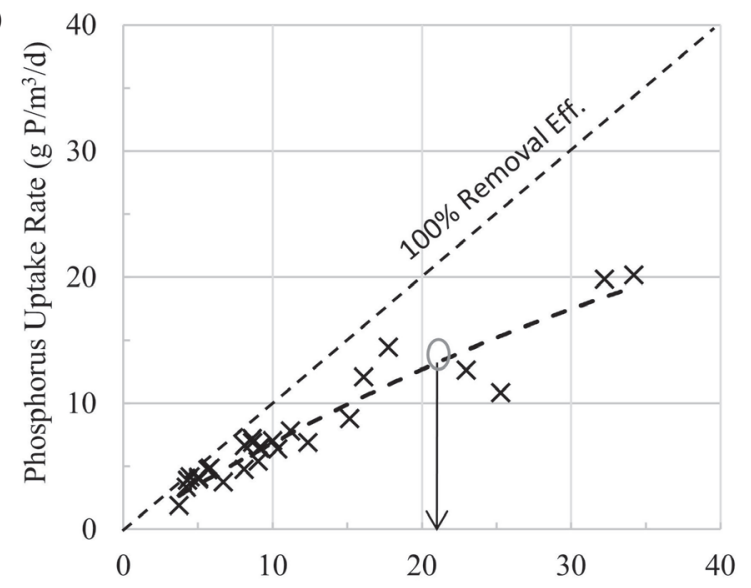

Phosphorus Applied Load (g P/m³/d)

Fig. 3. Applied load vs. uptake rate in photo-bioreactor for ammonia a), and phosphorus b). and 30 days at SBR total cycle time of 24 hours and was successful in completely removing ammonia from the medium. Also, it should be noted that the HRTs used in this study were less than the HRT of 24 hours used by Karya et al. (2013) and van der Steen et al. (2015) [9-10].

In order to assess the nutrient removal capacity, the relationships between the applied loads and uptake rates were plotted for ammonia and phosphorus in Fig. 3. The relationship between ammonia applied load and ammonia uptake load was close to $100 \%$ removal efficiency at low applied loads, as shown in Fig. 3a). The inflection point of this relationship indicates the optimum applied ammonia load of $50 \mathrm{~g} \mathrm{~N} / \mathrm{d} / \mathrm{m}^{3}$. The recommended ammonia applied load of $50 \mathrm{~g} \mathrm{~N} / \mathrm{d} / \mathrm{m}^{3}$ is comparable to results of previous lab experiments. At similar conditions, van der Steen et al. (2015) [9] obtained an ammonia uptake rate up to $66 \mathrm{~g} \mathrm{~N} / \mathrm{d} / \mathrm{m}^{3}$ in a lab-scale photo-bioreactor. Karya et al. (2013) [10] got a higher ammonia uptake rate up to $92 \mathrm{~g} \mathrm{~N} / \mathrm{d} / \mathrm{m}^{3}$. The ammonia concentrations in the influent wastewater used by van der Steen et al. (2015) and Karya et al. (2013) [9-10] were 66 and $50 \mathrm{mg} \mathrm{N} / 1$, respectively, which are higher than concentrations used in this study. Therefore, this research had higher applied ammonia loads and consequently higher uptake rates. As previously mentioned, studies about an open algal photo-bioreactor using low ammonia concentrations as the ones used in this study are limited.

The uptake of phosphorus as shown in Fig. 3b) is less than the uptake of ammonia. The inflection point of this relationship indicates an optimum applied phosphorus load of $22 \mathrm{~g} \mathrm{P} / \mathrm{d} / \mathrm{m}^{3}$. Ammonia and phosphorus removal efficiencies above $85 \%$ and $70 \%$, respectively, are expected when applied loads are below these recommended values. The efficiency of ammonia and phosphorus removal decreases considerably when applied loads are increased above these recommended levels. These applied ammonia and phosphorus loads correspond to HRTs of 5 to $6 \mathrm{~h}$, assuming average influent ammonia and phosphorus concentrations of 10-12 mg/L and 4-6 mg/L, respectively.

The $\mathrm{pH}$ of the influent wastewater ranged between 6.89 and 7 and then increased inside the reactor as it ranged between 8.12 and 8.9 throughout the experiment period. Thus, we concluded that the $\mathrm{pH}$ values increase as algal activity increases due to $\mathrm{CO}_{2}$ consumed during photosynthesis, as described in the literature. The influent wastewater has DO values between 2.2 and $3.5 \mathrm{mg} / \mathrm{L}$, 
with an average of $2.85 \mathrm{mg} / \mathrm{L}$. The DO values increased inside the bioreactor and ranged between $4.7 \mathrm{mg} / \mathrm{L}$ and $11.6 \mathrm{mg} / \mathrm{L}$ over the experimental period, with an average of $8.15 \mathrm{mg} / \mathrm{L}$, which is above $100 \%$ air saturation. However, DO concentration up to $16.8 \mathrm{mg} / \mathrm{L}$ was reported in the literature due to active photosynthesis and good growth of microalgae in the bioreactors [21].

Samples were taken from the photo-bioreactor at the end of the experiment, on day 110, for observation and identification of the dominant algal species. Scenedesmus, Spirulina, and Anomoeonels were observed, with dominance by the Scenedesmus species. Scenedesmus and Spirulina species pre-existing in the seeded biomass survived. As mentioned by Muñoz and Guieysse (2006) [12], Scenedesmus $s p$. has quick growth rates and dominates in continuous microalgal-based treatment systems. At medium loads, Scenedesmus $s p$. is the most dominant algal species. Ankistrodesmus, Closterium, and Anabaena pre-existing in the seeded biomass were diminished and the new species Anomoeonels appeared.

\section{Conclusions}

This paper demonstrated the success of an algal photo-bioreactor as a polishing step for the treatment of secondary wastewater effluent in a real WWTP. The system was tested at different HRTs and a fixed SRT of 15 days and showed good removal of ammonia and phosphorus. The best performance was obtained at HRT of $16.1 \mathrm{~h}$ for both organic and nutrient removal. However, for a more economical design, HRTs can be shortened to 5-6 h while maintaining expected removal efficiencies above $85 \%, 70 \%$, and $50 \%$ for ammonia, phosphorus, and COD, respectively. The recommended applied loads are $50 \mathrm{~g} \mathrm{~N} / \mathrm{d} / \mathrm{m}^{3}$ and $22 \mathrm{~g} \mathrm{P} / \mathrm{d} / \mathrm{m}^{3}$, respectively. We found that Scenedesmus was the dominant species. Scenedesmus and Spirulina species existing in the seeded biomass survived. A new species, Anomoeonels, appeared that did not exist in the seeded biomass. Wastewater treatment by algalbacterial reactors is a recent technology that needs further research to optimize the design criteria and operating conditions. Future investigations should concentrate on scale-up and modeling of algal photo-bioreactors.

\section{References}

1. TCHOBANOGLOUS G., BURTON F.L., STENSEL H.D., Metcalf \& Eddy Inc. (Editor). Wastewater Engineering: Treatment, Disposal, and Reuse, $4^{\text {th }}$ ed.; McGraw-Hill, Inc.: New York, 2003.

2. PITTMAN J.K., DEAN A.P., OSUNDEKO O. The potential of sustainable algal biofuel production using wastewater resources. Bioresource Technology, 102 (1), 17, 2011.

3. ZHU L., WANG Z., SHU Q., TAKALA J., HILTUNEN E., FENG P., YUAN Z. Nutrient removal and biodiesel production by integration of freshwater algae cultivation with piggery wastewater treatment. Water Research, 47 (13), 4294, 2013.
4. PARK J.B.K., CRAGGS R.J., SHILTON A.N. Recycling algae to improve species control and harvest efficiency from a high rate algal pond. Water Research, 45 (20), 6637, 2011.

5. BRENNAN L., OWENDE P. Biofuels from microalgae A review of technologies for production, processing, and extractions of biofuels and co-products. Renewable and Sustainable Energy Reviews, 14 (2), 557, 2010.

6. ACIÉN F.G., GÓMEZ-SERRANO C., MORALESAMARAL M.M., FERNÁNDEZ-SEVILLA J. M., MOLINA-GRIMA E. Wastewater treatment using microalgae: how realistic a contribution might it be to significant urban wastewater treatment?. Applied Microbiology Biotechnology, 100 (21), 9013, 2016.

7. DI TERMINI I., PRASSONE A., CATTANEO C., ROVATTI M. On the nitrogen and phosphorus removal in algal photobioreactors. Ecological Engineering, 37 (6), 976, 2011.

8. XIN L., HONG-YING H., KE G., YING-XUE S. Effects of different nitrogen and phosphorus concentrations on the growth, nutrient uptake, and lipid accumulation of a freshwater microalga Scenedesmus sp. Bioresource Technology, 101 (14), 5494, 2010.

9. VAN DER STEEN P., RAHSILAWATI K., RADA-ARIZA A.M., LOPEZ-VAZQUEZ C.M., LENS P.N. A new photoactivated sludge system for nitrification by an algal-bacterial consortium in a photo-bioreactor with biomass recycle. Water Science and Technology, 72 (3), 443, 2015.

10. KARYA N.G., VAN DER STEEN N.P., LENS P.N. Photooxygenation to support nitrification in an algal-bacterial consortium treating artificial wastewater. Bioresource Technology, 134, 244, 2013.

11. VALIGORE J.M., GOSTOMSKI P.A., WAREHAM D.G., O'SULLIVAN A.D. Effects of hydraulic and solids retention times on productivity and settleability of microbial (microalgal-bacterial) biomass grown on primary treated wastewater as a biofuel feedstock. Water Research, 46 (9), 2957, 2012

12. MUÑOZ R., GUIEYSSE B. Algal-bacterial processes for the treatment of hazardous contaminants: a review. Water research, 40 (15), 2799, 2006.

13. CHOI O., DAS A., YU C.P., HU Z. Nitrifying Bacterial Growth Inhibition in the Presence of Algae and Cyanobacteria. Biotechnology and bioengineering, 107 (6), 1004, 2010.

14. CHRISTENSON L., SIMS R. Production and Harvesting of Microalgae for Wastewater Treatment, Biofuels, and Bioproducts. Biotechnology Advances, 29 (6), 686, 2011.

15. BITOG J.P., LEE I.B., LEE C.G., KIM K.S., HWANG H.S., HONG S.W., SEO I.H., KWON K.S., MOSTAFA E. Application of Computational Fluid for Modeling and Designing Photo-bioreactors for Microalgae Production: A review. Computers and Electronics in Agriculture, 76 (2), 131, 2011.

16. XU M., LI P., TANG T., HU Z. Roles of SRT and HRT of an algal membrane bioreactor system with a tanks-in-series configuration for secondary wastewater effluent polishing. Ecological Engineering, 85, 257, 2015.

17. GONZÁLEZ-FERNÁNDEZ C., MOLINUEVO-SALCES B., GARCÍA-GONZÁLEZ M.C. Open and enclosed photobioreactors comparison in terms of organic matter utilization, biomass chemical profile and photosynthetic efficiency. Ecological Engineering, 36 (10), 1497, 2010.

18. BOONCHAI R., SEO G. Microalgae membrane photobioreactor for further removal of nitrogen and phosphorus from secondary sewage effluent. Korean Journal of Chemical Engineering, 32 (10), 2047, 2015. 
19. CHEIRSILP B., TORPEE S. Enhanced growth and lipid production of microalgae under mixotrophic culture condition: Effect of light intensity, glucose concentration and fed-batch cultivation. Bioresource Technology, 110, 510, 2012.

20. APHA, AWWA, WEF, Standard methods for the examination of water and wastewater, $21^{\text {st }}$ ed., American Public Health Association, Washington DC, 2005.
21. KRUSTOK I., ODLARE M., TRUU J., NEHRENHEIM E. Inhibition of nitrification in municipal wastewater-treating photobioreactors: Effect on algal growth and nutrient uptake. Bioresource Technology, 202, 238, 2016. 
